\title{
Mobilizing the police from the top down as public health partners in combatting COVID-19: A perspective from Vietnam
}

\author{
Hai Thanh Luong, ${ }^{*}$ Melissa Jardine, ${ }^{\dagger}$ and Nicholas Thomson ${ }^{\ddagger}$
}

\begin{abstract}
The coronavirus (COVID-19) was declared a global pandemic by the World Health Organization on 11 March 2020. The pandemic is having a profound impact on global order, the global economy, and the health and well-being of millions of people across the globe. As its impact continues to unfold, the relationship between public health capability and policing responses has become a focus of analysis. Vietnam has so far managed to avoid a health catastrophe, and, given its proximity to China, this bears further examination.

COVID-19 was first documented in Vietnam on 23 January 2020, when Ho Chi Minh City officials reported two confirmed cases involving people who had recently travelled from Wuhan, in Hubei province, China. At the time of writing, the last case recorded was "patient number 268," with 223 patients making a full recovery and no death toll after three months (Minh \& Bich, 2020; Viet-Phuong et al., 2020). Most COVID-19 cases have involved people travelling to Vietnam from overseas. Vietnam's effective response to COVID-19 is founded on its experience with the 2003 Severe Acute Respiratory Syndrome (SARS) outbreak, which involved significant collaboration with international agencies and foreign governments (Lucius, 2009).
\end{abstract}

\section{TOTAL STATE RESPONSE TO COVID-19}

Vietnam, alongside China, is one of few countries with a one-party state. In response to the emergence of COVID-19 in Wuhan, the Vietnam Party-State (VPS) directed all levels of government and society to respond to the unfolding situation and take immediate measures to prevent and control the epidemic (Viet-Phuong et al., 2020). The General SecretaryPresident of the VPS invoked the national slogan to officially declare that "fighting the COVID-19 epidemic is like fighting the enemy," referring to Vietnam's protracted fight for independence in the 20th century from colonial French and United States administrations. Through positioning the state response to COVID-19 as a fight to protect national security, the Government and Party continued a narrative which protects and entrenches Communist Party legitimacy, protects economic and social stability, and protects the well-being of the people, while mobilizing the entire political system and all citizens in the response (Lucius, 2009).

One part of Vietnam's Communist state response is the activation of a permanent steering committee on disease prevention and control, the National Steering Committee for COVID-19 (NSCC). It includes representation from multiple Government ministries, departments, branches, mass organizations (e.g., Women's Union and Ho Chi Minh Youth Union), and officials and soldiers from the armed forces and law enforcement agencies (Minh \& Bich, 2020). The NSCC coordinated the implementation of strict public health and security measures to prevent the spread of COVID-19.

Police and security forces have emerged as key resources in the response to the global pandemic. In Vietnam, the Ministry of Public Security (MPS) established their own Steering Committee for the Prevention and Combat of COVID-19, with the Deputy Minister as its head. Subsequently, police officers at all levels of government were instructed to be more active in disease prevention and control, including receiving instructions from public health leaders. Throughout the state, under the leadership of the VPS, the NSCC, and the NSCC's branch of MPS, police and security forces deployed their professional training to control, monitor, and limit community transmission of the virus by enforcing a community-wide lockdown.

There are four key approaches to COVID-19 initiated under the supervision of the NSCC that are relevant to the police and security forces. These approaches were adopted in staged combination depending on specific circumstances, speed of spreading of the virus, and size of population and were designed to ensure the effectiveness of each stage of the campaign to prevent and control COVID-19 in Vietnam. Firstly, the police and security forces were mobilized to provide information and education to the community about the risks of COVID-19 transmission and what actions were required to prevent transmission. Secondly, security guards were deployed to cooperate with local administrators and public health officials to isolate COVID-19 patients or people under quarantine and to secure the surrounding area. Thirdly,

Correspondence to: Dr Hai Thanh Luong, Honorary Principal Research Fellow, School of Global, Urban and Social Studies, RMIT University, Building 37, Level 5, Room 44, 411 Swanston Street, Melbourne, Vic 3000, Australia. E-mail: haithanh.luong@rmit.edu.au

To cite: Luong, H. T., Jardine, M., \& Thomson, N. (2020). Mobilizing the police from the top down as public health partners in combatting COVID-19: A perspective from Vietnam. Journal of Community Safety and Well-Being, 5(2), 57-59. https://doi.org/10.35502/jcswb.132

(C) Author(s) 2020. Open Access. This work is distributed under the Creative Commons BY-NC-ND license. For commercial re-use, please contact sales@sgpublishing.ca.

g.PUBLISHING Published by SG Publishing Inc. CSRA Official publication of the Community Safety Knowledge Alliance. 
security forces monitored and guarded specific locations 24 hours a day where new COVID-19 cases emerged. Finally, police investigated other crimes associated with the pandemic, such as the spread of misinformation, including with respect to the Government and Party's national response. At least seven offenders were arrested for attempting to embezzle the State's budget investment to distribute medical equipment in the Hanoi Centre of Disease Control.

\section{"NOTHING IN, NOTHING OUT"}

In addition to physical distancing, governments across the globe have sought to prevent the spread of COVID-19 through public health interventions such as lockdowns and restrictions on movement. Vietnam's experience and capability to mobilize the community, government agencies, and law enforcement institutions in responding to new infectious disease outbreaks appears to have been advantageous in mitigating the full impact of SARS since 2003 (Lucius, 2009). Moreover, Asian countries with close proximity to the source of the outbreak, which might usually be expected to bear the brunt of virus spread, demonstrated preparedness through a number of effective responses, including high- and lowtechnology solutions, such as in Singapore and Vietnam (Heymann, Mackenzie, \& Peiris, 2013). Crucially, China's neighbours' rapid responses to the threat of an epidemic in the early stages averted the crisis now seen in countries much farther afield.

One of the most prominent strategies in policing applied in Vietnam is "nothing in, nothing out" —which refers to denying unauthorized people entry or exit to and from isolated areas or their peripheries without official permission. Furthermore, in the isolated zones, police officers are always present 24 hours a day 7 days a week to maintain compliance with the lockdown (see Figure 1). A joint team comprising multiple agencies, including police, was created to inspect all people moving in and out of their provincial boundaries, particularly at cross-border points between Vietnam and its neighbouring countries such as China, Cambodia, and Lao PDR, as well as at its international airports (Minh \& Bich, 2020; Viet-Phuong et al., 2020).

A strict lockdown approach was implemented initially in Vietnam to control and isolate approximately 10,000 people

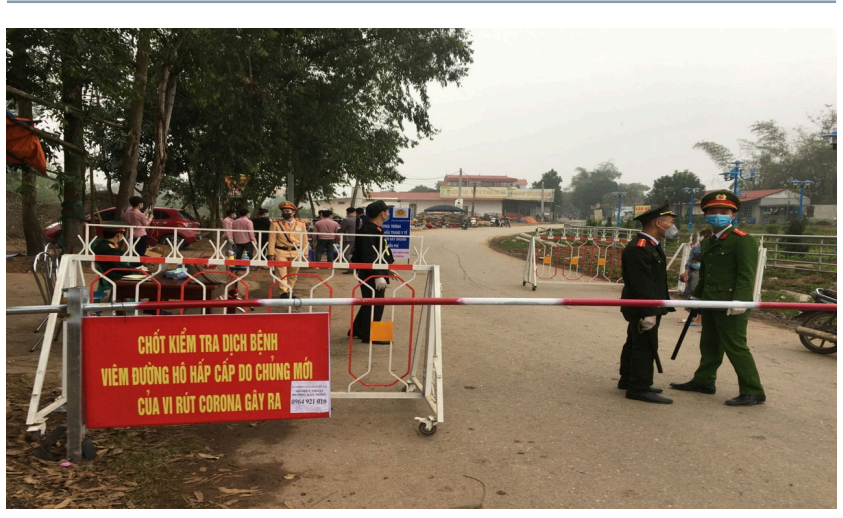

FIGURE 1 Nobody in, nobody out. Isolated COVID-19 zone at Son Loi Commune, Vinh Phuc Province, Vietnam of Son Loi village (about 40 kilometres from Hanoi). In Son Loi, five people were infected with the virus in mid-February 2020, which resulted in the village being isolated under strict quarantine for 21 days to ensure no new cases emerged before relaxing the quarantine conditions. After successfully containing COVID-19 infections in Son Loi, the risk of infections coming from overseas travelers became the focus, particularly after patient number 17 arrived from Europe. As a result, the Government instituted mandatory 14-day quarantine at state facilities or voluntary camps. At the high point, there were more than 70,000 people in quarantine (Minh \& Bich, 2020; Viet-Phuong et al., 2020).

\section{COMMUNITY-BASED POLICING IN COVID-19}

There is no agreed definition of community policing, though it is generally underpinned by key principles, including focusing on building ties and working closely with local residents as well as establishing relative trust between police and community through interactions with people and the public (Jenkins, 2016; Tyler, 2011). In Vietnam, the Party-State ideology requires that national security bodies, including the police, loyally serve the Communist Party (Hai, 2019; Jardine, 2020). Since their establishment in 1945, the Vietnamese police have acted as the "sword and shield of the Party" to protect the regime (Grossheim, 2018). In the context of COVID-19, protecting the health of the people in turn protects the legitimacy of the Party. As a result, one of the most distinguishing features of Vietnam's COVID-19 response resembles a community policing model, where frontline officers, who have extensive capability for community engagement at the ward and commune level, exchange information related to the VPS directives on prevention and containment strategies. This relationship enables police to use discretion in urgent situations and have up-to-date intelligence on potential risks (Turner \& Rowe, 2020). In response to the spread of COVID-19, Vietnamese police distributed essentials, such as face masks, hand wash and sanitizer, among other medical provisions. In addition, at the community level, police provided their accommodations to support local residents who were required to shelter temporarily in isolation. In turn, local residents cooperated with police and provided reliable information relating potential COVID-19 cases to police officers through public notification boxes or private hotlines.

According to their duties under the NSCC and in cooperation with public health officials, police checked all residences and commercial and entertainment centres to prevent the spread of COVID-19 by knocking on every door to ensure compliance with the lockdown orders, including monitoring people who had returned from overseas and were in isolation. At each house, police examined the household registration book, educated the owner about their responsibility to maintain accurate records, and reminded the owner to declare relevant information transparently. Police also reminded residents to ensure relatives returning from overseas were quarantined. For example, after two weeks with no new cases in the whole of country, when COVID-19 patient number 17 was detected in Truc Bach Street, Hanoi (see Figure 2) on 6 March 2020, all ward police officers were deployed to guard the quarantine zone and check all accommodation whether owned or rented in the surroundings. 


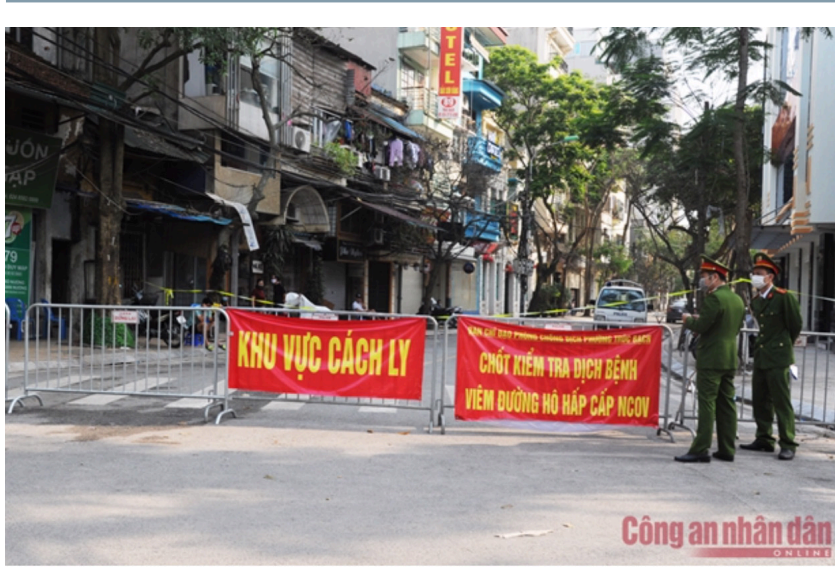

FIGURE 2 Lockdown at COVID-19's infectious areas at the Truc Bach ward, Hanoi

Police enforced home-based quarantine for all residents in Truc Bach Street to detect any residents who may have been in contact with infected patients or even passed through contagious areas. To do so, police went door-to-door checking in with local residents and traced patient number 17's routes and tracks before infecting.

\section{FINAL THOUGHTS}

Nationwide lockdowns in Vietnam resulted in trade-offs between strict lockdown measures and limitations on freedom of movement. While lockdowns and quarantine are appropriate responses to prevent the spread of a contagious virus, Vietnam's approach was strictly enforced and incredibly effective. The extent of local dissent to the NSCC and MPS instructions are unclear, particularly because publication of information or views which are unsupported by the Party may lead to arrest (Minh \& Bich, 2020). In contrast, some Western democracies, such as the United States, have seen people outdoors protesting their rights to freedom of movement-even in a pandemic.

With respect to intense police involvement in the pandemic, one of the risks for frontline ward-level police officials is that by going door-to-door to inform, educate, and monitor the community for compliance, they may be at increased risk of infection due to their close proximity to suspected cases, patients, and their relatives. It is unclear to what extent police received professional training regarding the prevention and control of COVID-19. Nonetheless, the policing structures provided important mechanisms for disseminating information and personal protective equipment (PPE) to frontline officers, as seen by a police branch of the Women's Union that mobilized to distribute PPE and food to officers (Bo Cong an, 2020).

Vietnam's capability for expansive local-level police engagement in a pandemic provides useful insight into different models of community policing. It demonstrates how a close relationship between police and local residents as a form of community-based policing can work productively (Grossheim, 2018; Palmer, 2020). In the Vietnamese context, the application of "zero tolerance policing" amid high rates of virus spread may have ensured high community compliance with the VPS's COVID-19 directives on physical distancing regulations. In Vietnam, people can be sentenced to up to seven years in jail for the use of force or threats towards authorities executing their duties. Vietnam's leaders appear to have strong support from the community for their response to COVID-19 and acceptance of the limitations on personal rights. Nonetheless, it remains to be seen which aspects of the Vietnamese approach can be applied in other countries.

\section{CONFLICT OF INTEREST DISCLOSURES}

The authors declare that there are no conflicts of interest.

\section{AUTHOR AFFILIATIONS}

*School of Global, Urban, and Social Studies, RMIT University, Australia; ${ }^{\dagger}$ Board of Directors and Secretary, Global Law Enforcement and Public Health Association (GLEPHA) and Centre for Law Enforcement and Public Health (CLEPH), Australia; ${ }^{\ddagger}$ London School of Hygiene and Tropical Medicine, Senior health advisor to the Australian National University's Pacific Security College

\section{REFERENCES}

Bo Cong an. (2020). Phu nu van phong co quan canh sat dieu tra, Cong an tinh An Giang voi nhung viec lam y nghia trong phong, chong COVID-19 [Women Office of Police Investigation Agency, An Giang Provincial Police with Meaningful Works in COVID-19]. 1 April. Retrieved from http://bocongan.gov.vn/tin-tuc-su-kien/su-kien-chaomung-ngay-thanh-lap-nganh/phu-nu-van-phong-co-quan-canh-satdieu-tra-cong-an-tinh-an-giang-voi-nhung-viec-lam-y-nghia-trong-phongchong-dich-covid-19-s 14-27689.htmlefbclid=IwAR24iaUWOGFoz|Xa xUNDHkMovC-OQrXvKNPucDolW7eh18SwyOYZ5oTrVBM

Grossheim, M. (2018). The "Sword and Shield of the Party": How the Vietnamese people's public security forces portray themselves. Intelligence and National Security, 33(3), 439-458.

Hai, T. L. (2019). Transnational drug trafficking across the Vietnam-Laos Border. Cham, Switzerland: Palgrave MacMillan.

Heymann, D., Mackenzie, J., \& Peiris, M. (2013). SARS legacy: Outbreak reporting is expected and respected. The Lancet, 381(9869), 779-781. doi: 10.1016/50140-6736(13)60185-3

Jardine, M. (2020). A southern policing perspective and appreciative inquiry: An ethnography of policing in Vietnam. Policing and Society, 30(2), 186-205. doi: 10.1080/10439463.2019.1680673

Jenkins, M. (2016). Police support for community problem-solving and broken windows policing. American Journal of Criminal Justice, 41(2), 220-235.

Lucius, Casey. (2009). Vietnam's political process: How education shapes political decision making. New York: Routledge.

Minh, V., \& Bich, T. (2020). The secret to Vietnam's COVID-19 response success: A review of Vietnam's response to COVID-19 and its implications. 18 April. Retrieved from https://thediplomat.com/2020/04/ the-secret-to-vietnams-covid-19-response-success/

Palmer, D. (2020, 8 April). Pandemic policing needs to be done with the public's trust, not confusion. Retrieved from https://theconversation. $\mathrm{com} /$ pandemic-policing-needs-to-be-done-with-the-publics-trust-notconfusion-135716

Turner, L., \& Rowe, M. (2020). Police discretion and the coronavirus pandemic. Retrieved from https://bscpolicingnetwork.com/2020/04/21/ police-discretion-and-the-coronavirus-pandemic/

Tyler, T. (2011). Trust and legitimacy: Policing in the USA and Europe. European Journal of Criminology, 8(4), 254-266.

Viet-Phuong, L., Thanh-Hang, P., Manh-Toan, H., Minh-Hoang, N., KhanhLinh, N., Thu-Trang, V., ... Quan-Hoang, V. (2020). Policy response: Social media and science journalism of the sustainability of the public health system amid the COVID-19 outbreak: The Vietnam lessons. Sustainability, 12, 1-27. doi: 10.3390/sul2072931 